せる.この CM は Fig. 4 および Fig. 5 のごとく導 管 $\mathrm{DT}_{\mathrm{L}}$ の端縁に通孔 $\mathrm{HL}$ をあけた金属板電極 $\mathrm{MPP}_{1}$ を固着し，また導管 $\mathrm{DT}_{\mathrm{R}}$ の端縁には通孔 $\mathrm{GHL}$ (多数 の小孔をあけたもので，これは容量の減少を防止するた めである）をあけた金属板に電気絶縁物 Ins を施した 電極 $\mathrm{MPP}_{2}$ を固定し, その $\mathrm{MPP}_{2}$ と $\mathrm{MPP}_{1}$ との上方 を頂点 $\mathrm{r}$ として図のように対向構成させ，この電極間で 形成する空間に頂点 $\mathrm{r} て ゙$ 接続した金簿 $\mathrm{Au}$ を垂下させ, $\mathrm{Au}$ と $\mathrm{MPP}_{1}$ で一方の電極とし, $\mathrm{MPP}_{2}$ を他方の電極 としたコンデンサー $\mathrm{CM}$ を作り，前者をアース $\mathrm{E}$ に， 後者を共振回路の一端に接続する. 上記 $\mathrm{Au}$ がてんび んビームの変化に応動する可動電極である.

\section{2 結語}

上述の本装置は一般に使用されているエアーダンパー そのまをを利用できる（ダンパーシリンダーのみの一部 改良)、また構造が簡単であるにかかわらずその感度は 非常に高い. 本制御装置はモータ一方式の高周波自動て えびえ（報交に揭載）の制御にも応用できる.

本研究にあたり，終始御烈䉆なる御指導を賜わりまし た恩師石館守三先生につつしんで感謝いたします。また 有益な御助言をいただいた本学講師嘉村祐一博士に深く お礼申しあげます。

(1959 年 5 月 21 日, 本会関東支部会飞発表) (昭和 35 年 11 月 15 日受理)

\section{微量分析用光電光度計の試作}

平野 四蔵・水池敦・飯田 芳男*

$$
1 \text { 緒言 }
$$

吸光光度分析の感度を高める一つの方法は, 呈色液の 最終液量を少なくするように発色操作を行ない，なるべ く光路の長い微小吸収セルを用いて吸光度を測定するこ とであるが，現在市販の光電光度計はこの要求を満たす には不十分であり，また，Beckman 分光光度計用の微 小吸収セルが Kirk，Lowry らによって試作研究され た1)2）がまだ市販されるに至ってはいない，極微量成 分を分離濃縮して定量する場合などこのような試みはき わめて有用なので，著者らは工業分析化学的見地から，

i ）測定精度は従来の光度計に劣らず， ii）必要液量 $0.5 \mathrm{ml}$ 以下, 吸収セルの長さ $2 \mathrm{~cm}$, iii) 装置の構造,

\footnotetext{
* 東京大学工学部応用化学科工業分析化学教室
}

取扱操作が簡単であることなどを目標に光電光度計およ び微小吸収セルを試作し，ほほ满足すべき結果を得た。

\section{2 試作装置の概要}

\section{$2 \cdot 1$ 数小吸収セル}

Fig. 1 に示した 3 種（ガラス製）を試作した. C形 が液の出し入れ，洗浄，製作など最も容易であったので 3 以下の実験は $\mathrm{C}$ 形を用いて行なった。必要液量は $\mathrm{A}$. 形, B形が約 $0.2 \mathrm{~m} l, \mathrm{C}$ 形は約 $0.3 \mathrm{~m} l$ であった。

\section{$2 \cdot 2$ 本体の構造}

Fig. 2 に光学系を示した. 本装置では, 幅 $3 \mathrm{~mm}$, 長さ $20 \mathrm{~mm}$ の微小吸収セル中を径 $1.5 \mathrm{~mm}$ の光が通る ので，吸収セルの位置がわずかにずれても大きな誤差と なる.このために，対照液と試料溶液を二つの吸収セル に入れて交互に光路中に移動させて指針調整と測定を行 なう普通の方式は避け，セルホルダーを一つとして固定 し，Fig. 2 に示したごとく，鏡 i， i' を設けて光を側 路（図中の破線）に通しうるようにし，その途中にある 可变絞り $\mathrm{n}$ で対照液の吸収を置き換える方式とした。

測定操作は次のように行なう。まず微小吸収セルに対 照液を入れ光路をセル側にし, シャッター b 堌幅回路
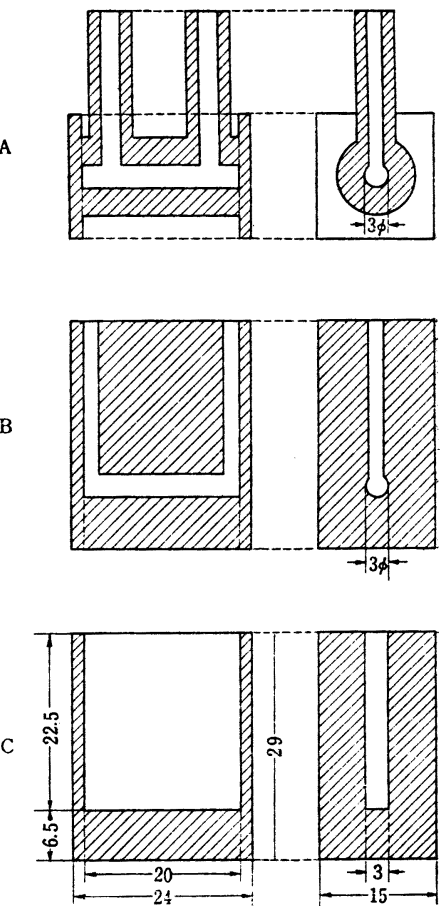

Fig. 1 微小吸収セル（ガラス製，破線部。 は貼り合せ，寸法は単位 $\mathrm{mm}$ ) 


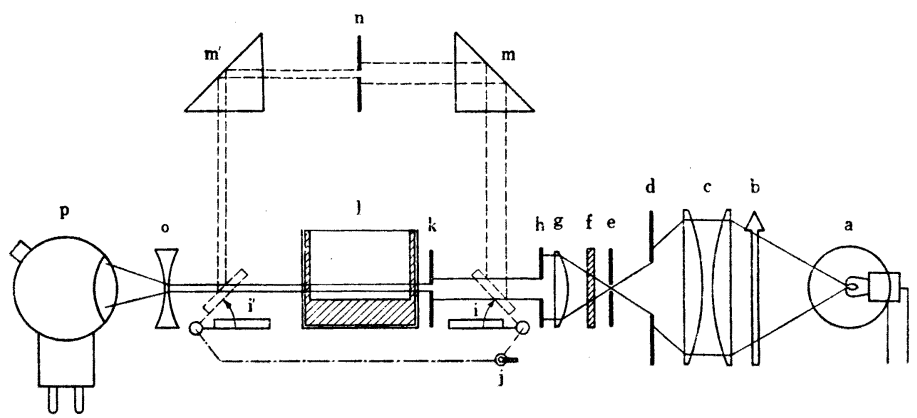

Fig. 2 試作 光電光度計 の光学系

$a:$ 光源ランプ

$\mathrm{b}:$ :シャッター

c : 凸レンズ

$\mathrm{d}:$ 可変校

$\mathrm{e}:$ 小孔

f : 色フィルター

g : 凸レンズ

$\mathrm{h}$ : 固定较

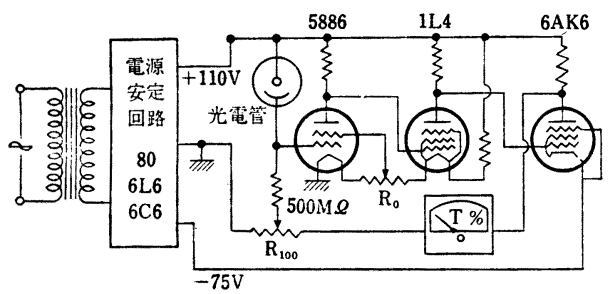

Fig. 3 増 幅 回 路

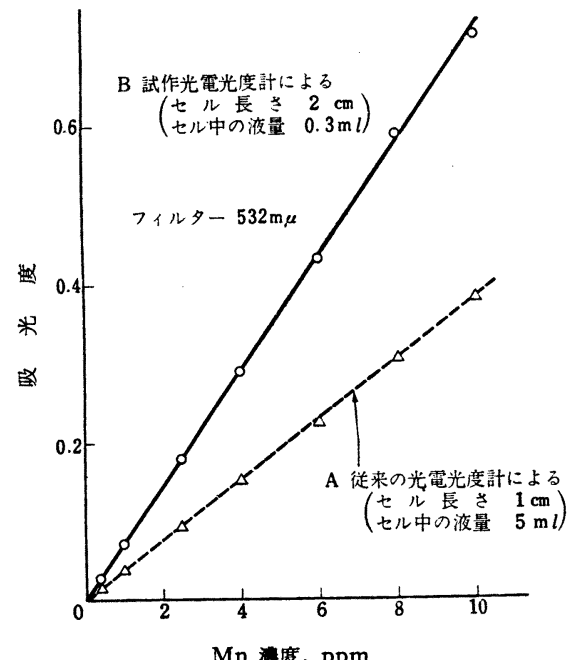

Fig. 4 過マンガン酸標準液によるマンガン検量線

(Fig. 3) の抵抗 $\mathrm{R}_{0}$ でメータ一の指針を透過率 0\%に, 可変絞り $\mathrm{d}$ と増幅回路の抵抗 $\mathrm{R}_{100}$ で $100 \%$ に調整(以下 0 合せ, 100 合せと記する) したのち,つまみ $\mathrm{j}$ を倒し i, $\mathbf{i}^{\prime}:$ : 鏡

$j$ : 鏡回転つまみ $\left(i, i^{\prime}\right.$ 連動)

$\mathrm{k}:$ 小孔 $(1.5 \mathrm{~mm} \phi)$

1: セルホルダーおよび微小吸収セル

$\mathrm{m}, \mathrm{m}^{\prime}:$ プリズム

$\mathrm{n}:$ 可変校り

o: : 凹レンズ

$\mathrm{p}$ : 光電管

て鏡を回転し光を側路に通し可变絞り nでふたたび 100 合せを行なう. 以上の操作を繰り返したのち同じ微小吸 収セルに試料溶液を入れ替兄, 光を側路に通した状態で 前と同様に 0 合せ，抵抗 $R_{100}$ で 100 合せを行なったの ち（このとき可変絞り $\mathrm{n}$ は絶対動かさない)，ただちに つまみ $\mathbf{j}$ を起して光を吸収セル中に通せばそのときの指 針が透過率（また吸光度）を示す。この方式では可变 絞り $\mathrm{n} の$ 調整は微小吸収セル, 対照液が変らない限り一 度行なうだけでよいはずであるが, 試作した装置では絞 りの位置が光源に近く温度の影響を受けることや工作上 の欠宿などにより，1系列の測定（30 分間位）ごとに調 整し直す必要があった. しかし, 微小吸収セルは一つし か使わないから普通の方式のように二つの吸収セルの差 異にもとづく誤差はさけられる. また，光源ランプの明 るさの変動をできるだけ少なくするためにトランジスタ 一式定電圧装置を用いた. 増幅回路は Fig. 3 に示すご とく, 得られる光電流が小さいので直流増幅 3 段とし負 帰還を十分かけた回路とした.

3 測定值の再現性と検量線の直線性

過マンガン酸カリウム標準液を用いて作成した検量線 を Fig. 4 亿示す. 数回の測定值のバラッキは $1 \%$ 以下 で, 再現性, 直線性とも従来の光電光度計（平間理化 製, 吸収セルの長さ $1 \mathrm{~cm})$ に劣らなかった。なお, 試作 装置による吸光度の測定は微小吸収セルを少量の水と測 定すべき標準液 $0.2 \mathrm{ml}$ で各 1 回洗浄後同じ標準液 0.3 $\mathrm{m} l$ を入れて行なった. この結果から, 測定溶液が 0.5 $\mathrm{m} l$ 市れば微小吸収セルを毎回乾燥させて行なう必要が ないことがわかった。 


\section{4 白金およびコバルトの検量線}

実際試料への応用の予備実験として, 標準液をビーカ - $(50 \mathrm{ml})$ にとり湯浴中で乾固後発色操作を行ない検 量線を作成した. Fig. 5 は塩化第一スズ法3)による白金 の検量線で, 塩酸 $(1+7)$ と $3.5 M$ 塩酸酸性の $1 M$ 塩 化第一スズ溶液を加えるだけの最も簡単な操作の例であ る. また，Fig. 6 はニトロソ $\mathrm{R}$ 塩法4)によるコバルト

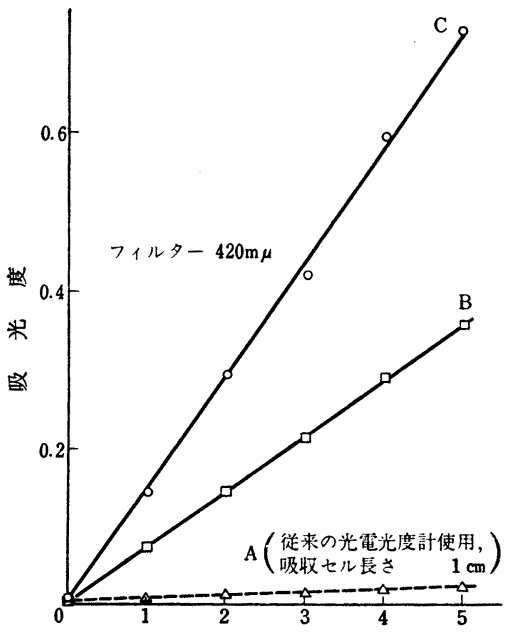

Pt 量, $\gamma$

Fig. 5 白金検量線

\begin{tabular}{|c|c|c|}
\hline \multicolumn{2}{|c|}{ 試薬添加量 $(\mathrm{m} l)$} & 最終液量 \\
\hline $\mathrm{HCl}(1+7)$ & $1 M \mathrm{SnCl}_{2}$ & $(\mathrm{~m} l)$ \\
\hline 8.0 & 2.0 & 10 \\
\hline 0.8 & 0.2 & 1 \\
\hline
\end{tabular}

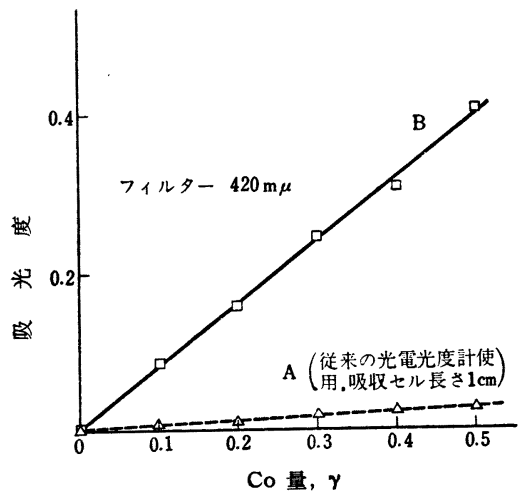

Fig. 6 コバルト検量線

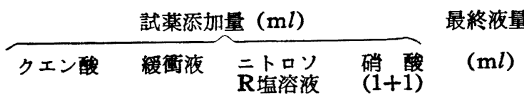

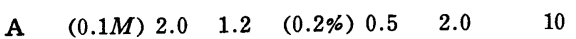

$\begin{array}{llllll}\text { B } & (0.05 M) 0.4 & 0.15 & (0.05 \%) 0.2 & 0.2 & 1\end{array}$
の検量線で，クエン酸 (0.1 または $0.05 M)$ とホウ酸 塩ーリン酸塩繮衝液を加えて試験紙で $\mathrm{pH} 8$ 亿調節後二 トロソ $\mathrm{R}$ 塩溶液 $(0.2$ または $0.05 \%)$ を加え湯浴中で 3 分間加熱後水冷し，さらに硝酸 $(1+1)$ を加えふたたび 3 分間加熱し, 冷却後水を加えて一定量とし, 試薬溶液 を対照液として吸光度を測るという複雑な操作を伴なう 例である.この場合には全液量が $0.5 \mathrm{ml}$ になるように 操作することは困難であった。

これらの結果から，試作した装置を用いることにより 従来の光電光度計を用いる場合に比べ精度を落さずに感 度を 10〜40 倍高めうることがわかった．なお，全液量 が $0.5 \mathrm{~m} l$ （加熱などの操作を伴なう場合は $1 \mathrm{~m} l$ ) 以下 になるように発色操作を行なうためには，特殊な操作法 を用いなければ十分な精度は望めないと思われる。

終りに装置の試作に協力された平間理化研究所に対し 感謝の意を表する。

（昭和 35 年 11 月，本会第 9 年会講演）

\section{交献}

1) P. L. Kirk, R. S. Rosenfels, D. J. Hanahan: Anal. Chem., 19, 355 (1947).

2) O. H. Lowry, O. A. Bessey : J. Biol.Chem., 163, 633 (1946).

3) E. B. Sandell : "Colorimetric Determination of Traces of Metals", 3 rd Ed., p. 726(1959).

4) 水池 敦, 飯田芳男, 平野四藏：工化，61，1459 (1958).

（昭和 36 年 1 月 30 日受理）

\section{ポリビニルアルコールの紫外吸収}

\section{スペクトルの定量的考察}

西 野 豊*

ポリビニルアルコール（以下 PVA と略す）の紫外吸 収スペクトルについては多くの報告がある1 6)。水溶液 で $225 ， 280$ および $325 \mathrm{~m} \mu$ 付近にそれぞれ極大を有す る三つの山が認められ，その帰属をめぐって論争が行な われたが, 現在はこれらのピークが PVA 主鎖中の-CO. $(\mathrm{CH}=\mathrm{CH})_{n}$ 構造の $n=1,2$ および 3 （または 3 以上） に対応するとされている. しかし，これらのピークは定 量的にはあまり考察されていないので, 著者がPVAの 品位との関連において若干検討した結果を以下に報告す る.

PVAの紫外吸収スペクトルをモデル的に示すと Fig.

*倉敷レイヨン株式会社富山工場 